\title{
ABOVEGROUND BIOMASS BASIC DENSITY OF HARDWOODS TREE SPECIES
}

\author{
Rudolf Petráš, Julian Mecko, Danica Krupová \\ National Forest Centre - Forest Research Institute in Zvolen Slovak Republic \\ Andrej PažitnÝ \\ Pulp and Paper Research Institute \\ Slovak Republic \\ (Received February 2020)
}

\begin{abstract}
The influence of tree species on basic density of wood, bark and small-wood was investigated here. Experimental material was obtained from 73 trees of 7 tree species, namely alder (Alnus glutinosa (L.) Gaertn.), beech (Fagus sylvatica L.), birch (Betula pendula Roth.), hornbeam (Carpinus betulus L.), Black locust (Robinia pseudoacacia L.), Sessile oak (Quercus petraea (Matt.) Liebl.) and Turkey oak (Quercus cerris L.) from the territory of Slovakia. Wood and bark samples were taken from discs cut from three trunk sections and from small-wood and branch parts coming from tree crowns. The volume of green samples was measured in graduated cylinders with a precision of $1 \mathrm{ml}$; a dry matter was measured with a precision of $0.01 \mathrm{~g}$. The statistically significant effect has been shown in tree species, biomass fractions and locations on the tree. The average basic density of all species varies from 440 to $650 \mathrm{~kg} \cdot \mathrm{m}^{-3}$ for wood, for bark it is $380-670 \mathrm{~kg} \cdot \mathrm{m}^{-3}$ and for small-wood outside bark it reaches $490-650 \mathrm{~kg} \cdot \mathrm{m}^{-3}$. Alder and Black locust tree species have the lowest and highest wood density, Black locust and Turkey oak of bark and alder and Turkey oak of small-wood.
\end{abstract}

KEYWORDS: Basic density, biomass, wood, bark, small-wood, hardwoods.

\section{INTRODUCTION}

Wood is a major component in tree biomass production and its bark constitutes a natural complement. Their composition varies on trees according to the tree species, the environment in which the trees grow and also their age. When used economically, their quantity is mostly expressed in volumes in $\mathrm{m}^{3}$. For a broader and more objective assessment of biomass production, for example, for calorific value content determination or for comparison with other plant communities, biomass must also be quantified in weight units. In order to avoid repeated 
determination of biomass production in weight units again, it is sufficient to convert its known volume in $\mathrm{m}^{3}$ to weight. For this procedure it is necessary to know its density according to the components in which the volume is expressed. Although density is generally expressed as a ratio of weight and volume of a particular component, in practice, basic density is applied as a ratio of weight $(\mathrm{kg})$ after its drying and the saturated (green) volume $\left(\mathrm{m}^{3}\right)$.

Wood density is most frequently stated in published sources and most authors associate it with its mechanical properties. Niemz and Sonderegger (2003) derived such a connection from literature for approximately 100 tree species. Soft deciduous species have the lowest densities, followed by softwoods and hardwoods. This is how the basic density of wood is arranged according to other authors too. Trendelenburg (1939) in Šmelko et al. (1992) states the basic density of $370-470 \mathrm{~kg} \cdot \mathrm{m}^{-3}$ for softwoods and $510-570 \mathrm{~kg} \cdot \mathrm{m}^{-3}$ for hardwoods. Požgaj et al. (1997) states the value of $370 \mathrm{~kg} \cdot \mathrm{m}^{-3}$ for spruce, fir and poplar, $440 \mathrm{~kg} \cdot \mathrm{m}^{-3}$ for pine, $560 \mathrm{~kg} \cdot \mathrm{m}^{-3}$ for beech and $600-650 \mathrm{~kg} \cdot \mathrm{m}^{-3}$ for Black locust and hornbeam. Similar values are also stated by Knigge and Schulz (1966) in Pretzsch (2009). Thus, the poplar reaches $377 \mathrm{~kg} \cdot \mathrm{m}^{-3}$, softwoods $380-490 \mathrm{~kg} \cdot \mathrm{m}^{-3}$, hardwoods $520-560 \mathrm{~kg} \cdot \mathrm{m}^{-3}$ and Black locust up to $650 \mathrm{~kg} \cdot \mathrm{m}^{-3}$. Several authors state that the wood density varies not only by tree species but also with the vertical or radial location within the trunk or in the tree crown (Husch et al. 2003, Tomczak and Jelonek 2013) followed by the annual rings width, the proportion of early and late wood, the tree age and the site on which the tree grows (Zeidler and Borůvka 2016, Schönfelder et al. 2017, Jelonek et al. 2009). Matovič and Šlezingerová (1992) state that wood from spruce branches has significantly higher density $\left(570 \mathrm{~kg} \cdot \mathrm{m}^{-3}\right)$ than that of stem wood $\left(406 \mathrm{~kg} \cdot \mathrm{m}^{-3}\right)$. In Serbia, Klašnja, Kopitovič (1992) calculated the Black locust wood basic density in the range of $533-639 \mathrm{~kg} \cdot \mathrm{m}^{-3}$, with an average of $599 \mathrm{~kg} \cdot \mathrm{m}^{-3}$, and the influence of its provenances did not prove. Munoz and Anta (2010) calculated the basic density of the maritime pine wood in Spain in the $307-527 \mathrm{~kg} \cdot \mathrm{m}^{-3}$ range, with an average of 408 $\mathrm{kg} \cdot \mathrm{m}^{-3}$. Petty et al. (1990) investigated the wood basic density in the Norway and Sitka spruce trunks in relation to the width of tree rings and found that Sitka spruce had slightly higher values. Wimmer (1991) concludes from the example of pine in Austria that wood basic density is significantly influenced by the proportion of early and late wood. Repola (2006) gives model basic density of wood in Finland, according to the relative height on its trunk, in a narrow range, namely for pine $410-435 \mathrm{~kg} \cdot \mathrm{m}^{-3}$, spruce $385-386 \mathrm{~kg} \cdot \mathrm{m}^{-3}$ and for birch $475-478 \mathrm{~kg} \cdot \mathrm{m}^{-3}$. Vavrč́k and Gryc (2012) give the wood basic density of the English oak $\left(584 \mathrm{~kg} \cdot \mathrm{m}^{-3}\right)$ and Sessile oak $\left(673 \mathrm{~kg} \cdot \mathrm{m}^{-3}\right)$ of South Moravia. Koman and Feher (2015) state 568, 586 and $627 \mathrm{~kg} \cdot \mathrm{m}^{-3}$ for the wood of beech, Sessile oak and Turkey oak in Hungary. Petráš et al. (2010, 2019) and Pastor et al. (2017) derived basic density also for tree bark and branches. Banski, Dzurenda (2014) and Lieskovský (2015) give the wood basic density of plantation-grown fast-growing tree species.

To convert whole tree biomass from volume to weight units, it is necessary to know its density according to the components as indicated in volume units. Specifically, the density of large wood, its bark and small-wood (thin wood containing bark $<7 \mathrm{~cm}$ ). Subsequently, he continued to study the biomass density of four coniferous tree species, namely pine, fir, larch and spruce (Petráš et al. 2019). The average basic density of all four tree species is for wood from 373 to $508 \mathrm{~kg} \cdot \mathrm{m}^{-3}$, for bark 333-551 kg.m $\mathrm{m}^{-3}$ and for small-wood with bark $406-535 \mathrm{~kg} \cdot \mathrm{m}^{-3}$. For the purpose of biomass production, a wider research on the biomass density of forest tree species began in connection with the research on the calorific value production of poplar clone stands in Slovakia (Petráš et al. 2010, 2013). According to their results, wood of a Robusta clone has density of $400-450 \mathrm{~kg} \cdot \mathrm{m}^{-3}$ and an I-214 clone has approximately by $50 \mathrm{~kg} \cdot \mathrm{m}^{-3}$ lower wood density. The bark has lower wood density, about $370 \mathrm{~kg} \cdot \mathrm{m}^{-3}$. In the crown parts of trees, the basic density of wood and bark is approximately the same. Based on the results of the research into the density and calorific value 
of poplar clones, this research continues with the same focus for seven economically important deciduous tree species. Now, basic density research is in the first stage and after that research on calorific value and its production in forest stands will continue.

The aim of this work is to derive mean values of basic density of wood, bark and small-wood in above-ground biomass of alder, beech, birch, hornbeam, Black locust, Sessile oak and Turkey oak trees.

\section{MATERIAL AND METHODS}

Depending on the tree species, 10-12 trees were felled, which is a total of 73 trees for all 7 tree species (Tab. 1). The trees were selected from different areas of western, central and eastern Slovakia with altitudes from approximately $100 \mathrm{~m}$ to almost $1000 \mathrm{~m}$. The quality of sites on which trees grew is expressed by a site index varying from 16 to 36 . It expresses mean stand height, which would be reached at the age of 100 years in beech, Sessile oak and Turkey oak species, and at the age of 50 years in other tree species. Felled trees are best characterized by their diameter, height and age. Most have parameters of mature trees. Birch, alder and Black locust species are represented by several younger trees too.

Tab. 1: Characteristics of felled trees by tree species, diameters, heights, tree age, site index and altitudes of forest stands.

\begin{tabular}{|l|c|c|c|c|c|c|}
\hline \multicolumn{1}{|c|}{ Species } & Number of trees & DBH $(\mathrm{cm})$ & $\mathrm{h}(\mathrm{m})$ & Age (years) & Site index & Altitude $(\mathrm{m})$ \\
\hline Beech & 12 & $20-51$ & $21-39$ & $80-115$ & $24-36$ & $350-950$ \\
\hline Sessile oak & 11 & $23-58$ & $22-35$ & $80-135$ & $24-30$ & $275-520$ \\
\hline Turkey oak & 10 & $33-51$ & $21-34$ & $86-120$ & $24-28$ & $190-410$ \\
\hline Hornbeam & 10 & $18-48$ & $18-29$ & $70-114$ & $20-26$ & $270-510$ \\
\hline Birch & 10 & $23-47$ & $20-30$ & $40-65$ & $16-28$ & $165-970$ \\
\hline Alder & 10 & $29-57$ & $23-33$ & $45-90$ & $20-32$ & $255-530$ \\
\hline Black locust & 10 & $22-49$ & $14-29$ & $32-85$ & $18-24$ & $100-550$ \\
\hline In total & 73 & $18-58$ & $14-39$ & $32-135$ & $16-36$ & $100-970$ \\
\hline
\end{tabular}

Four wood samples with bark were cut from each tree. The first sample is a wood disc with bark cut off from the foot of the trunk. The second is the disc from the middle part of the trunk (approximately under the tree crown) and the third comes from the crown part of the trunk. The bark was separated from the wood from all three discs. There was a small amount of bark from the cut-off discs in proportion to the wood, and therefore another bark was peeled from the part of the trunk where discs were sawed. The fourth sample represented small-wood, i.e. wood of branches (with bark) thinner than $7 \mathrm{~cm}$. This sample consisted of 20-25 $\mathrm{cm}$ long branch cuttings selected from the middle part of the crown. On this sample, the wood and bark remained together. 511 samples were taken from all 73 trees, of which 219 were taken for wood and bark and 73 for small-wood.

The volume of green samples was measured 1-2 days after their removal, in calibrated $2000 \mathrm{ml}$ graduated cylinders to the nearest $1 \mathrm{ml}$. The large discs taken from trunks were cut in a radial direction to smaller triangular sections prior to their measurement. The samples examined had the volume of wood in the range of 868-1661 ml, bark 310-1321 $\mathrm{ml}$ and smallwood $681-1171 \mathrm{ml}$. All samples were then dried to a constant weight at $103 \pm 2^{\circ} \mathrm{C}$ and after that 
weighed to within $0.01 \mathrm{~g}$. Weight of wood was in the range of 442-1090 g, bark 215-873 g and small-wood 352-777 g. Basic density was calculated from each sample as a ratio of its dry weight (mass) and green (saturated) volume:

$$
\rho_{b=\frac{m_{0}}{V_{S}}}
$$

where: $\quad \rho_{b}-$ the basic density $\left(\mathrm{kg} \cdot \mathrm{m}^{-3}\right)$,

$m_{0}-$ the dry mass $(\mathrm{kg})$,

$V_{s}$ - the saturated volume $\left(\mathrm{m}^{3}\right)$.

The basic density variability was examined and the most important factors affecting it were determined. The ANOVA generalized analysis of variance (more factors and variables) by means of QC-Expert computer software (Kupka 2013) was used. The ANOVA based on principle of addition of variances of known predictors (factors or numerical variables) $\sigma_{i}^{2}$ and unknown ones (random) cause $\sigma^{2}$ residual to the total variance $\sigma^{2}$ total

$$
\sigma_{\text {total }}^{2}=\sum \sigma_{i}^{2}+\sigma_{\text {residual }}^{2}
$$

In this analysis of variance, 3 factors were used as predictors (species, biomass fraction and location on tree):

- Species with 7 levels - beech, Sessile oak, Turkey oak, hornbeam, birch, alder and Black locust,

- Biomass fraction with 3 levels - wood, bark, small-wood,

- Location on the tree with 4 levels - 3 locations on the stem (foot, middle of the trunk, middle of the crown) and 1 location on small-wood.

The additional 4 predictors (site index, age, diameter and height of tree) were numerical variables. The total analysis resulted in the ANOVA, where the total effect of all the factors and numerical variables on the biomass density was assessed. In addition, the ANOVA according to single factors was performed as well. The differences between the average values at single levels were tested by the Student's t-test (Scheffe's method).

\section{RESULTS AND DISCUSSION}

The effect of 7 predictors (an impact of three factors and four numerical variables on the number of 511 of density values) was analysed by ANOVA. We can state (Tab. 2) that their overall effect on the basic density of biomass is statistically significant, $\mathrm{p}$-value is less than the chosen significance level $\mathrm{p}=0.05$.

Tab. 2: The overall test if the predictors have any effect on the basic density.

\begin{tabular}{|l|c|c|c|c|c|}
\hline \multicolumn{1}{|c|}{$\begin{array}{c}\text { Source of the } \\
\text { variability }\end{array}$} & $\begin{array}{c}\text { Degrees of } \\
\text { freedom }\end{array}$ & Sum of squares & Mean square & F-statistic & p-value \\
\hline Total variability & 510 & 4704753 & 9225 & & \\
\hline Explained variability & 4 & 2191589 & & 1.86 & $2.05 \mathrm{E}-12^{*}$ \\
\hline Residual variability & 506 & 2513164 & 4967 & & \\
\hline
\end{tabular}


The ANOVA was also applied to determine the effect of the concrete predictors on the biomass density (Tab. 3). The statistically significant effect, p-value is less than the chosen significance level $\mathrm{p}=0.05$, was proven only at one factor (species) and three variables (site index, age and diameter of the tree). The parameter values predict a negative linear dependence of biomass density on all numerical variables. The biomass fraction, its location on the tree and the height of the tree do not have the statistically significant effect on biomass density.

Tab. 3: The amount of variance explained by the predictors (factors and variables) at the basic density.

\begin{tabular}{|l|c|c|c|c|}
\hline \multicolumn{1}{|c|}{ Factors } & Parameter & Sum of squares & F-statistic & p-value \\
\hline Species & - & 2009924 & 62.65 & $5.40 \mathrm{E}-58^{*}$ \\
\hline Biomass fraction & - & 21045 & 1.14 & $3.20 \mathrm{E}-01$ \\
\hline Location on the tree & - & 41532 & 1.51 & $2.12 \mathrm{E}-01$ \\
\hline Diameter at breast height & $-0,58472$ & 101409 & 11.23 & $8.63 \mathrm{E}-04^{*}$ \\
\hline Height & $-3,27237$ & 5849 & 0.63 & $4.26 \mathrm{E}-01$ \\
\hline Age & $-0,05690$ & 478304 & 57.72 & $1.48 \mathrm{E}-13^{*}$ \\
\hline Site index & $-1,07848$ & 114683 & 12.74 & $3.92 \mathrm{E}-04^{*}$ \\
\hline
\end{tabular}

The ANOVA showed that the tree species has the largest share in the explained variability and therefore the primary focus was on this factor. The average densities and their standard deviations were calculated for single levels of all three factors. Subsequently, Scheffe's pairwise comparisons tested the differences between the arithmetic means of all levels of a particular factor.

\section{Wood and bark basic density in relation to their location on the trunk}

Basic density variability of wood (Fig. 1) is relatively great. The average values are in the range of $420-660 \mathrm{~kg} \cdot \mathrm{m}^{-3}$ and variation coefficients vary from 5 to $10 \%$. Sessile oak and Turkey oak wood have greater variability, probably due to the presence of the heartwood wood. The density varies not only with tree species but also with the location on the trunk and it is not possible to state unambiguously in which its location on the trunk it is higher or lower. The Student's t-test confirmed statistically significant differences in the wood basic density from three locations on their trunk for most species. Significant differences are especially between margin locations (location 1 and location 3). The differences in the wood basic density among the locations on the trunk were not confirmed in the Black locust and Sessile oak.

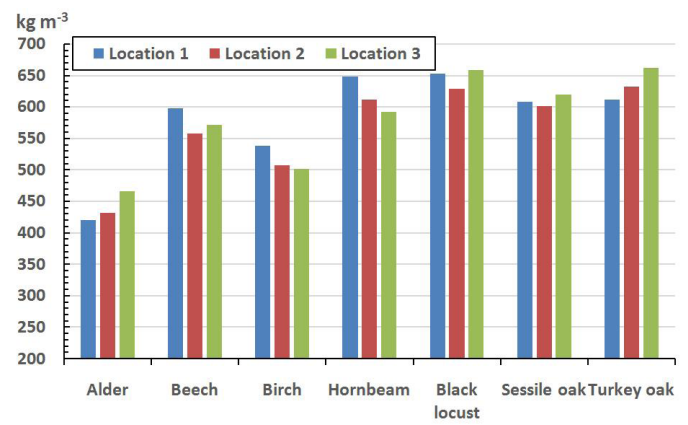

Fig. 1: The basic density of wood in dependence on a location on the trunk. (Location 1 - on the stem foot, 2 - at the middle of the stem, 3 - at the middle of the crown). 
The average bark density (Fig. 2) has not only a larger span (305-685 kg.m-3), but also greater relative variability than wood. The variation coefficients are in the range of $7-17 \%$. Due to its generally greater variability, differences in dependence on the location on the trunk were confirmed only in the Black locust and at the threshold of significance in alder. The Black locust has significantly lower bark basic density only in the stem foot (location 1). Alder has higher bark density in the crown part of the trunk compared to the other two locations.

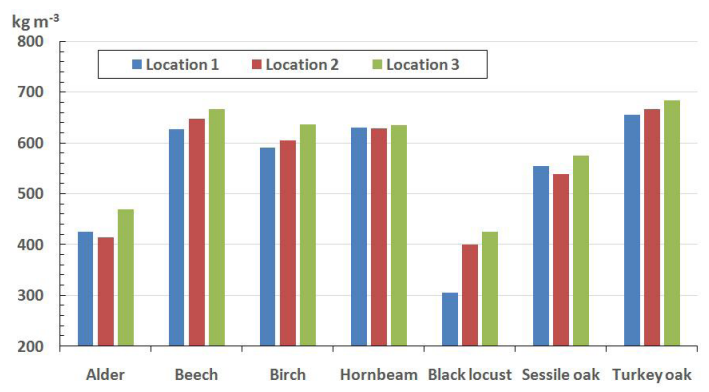

Fig. 2: The basic density of bark in dependence on tree species and the location on the trunk. (Location 1 - on the stem foot, 2 - at the middle of the stem, 3 - at the middle of the crown).

\section{Basic density of wood, bark and small-wood}

In forestry, biomass production is usually expressed in a volume unit $\left(\mathrm{m}^{3}\right)$ of wood, bark and small-wood for each tree species. To efficiently convert its production from volume to weight, the average basic densities $\left(\mathrm{kg} \cdot \mathrm{m}^{-3}\right)$ of the mentioned fractions were derived for all seven tree species (Fig. 3). Wood has average values in the range of $440-650 \mathrm{~kg} \cdot \mathrm{m}^{-3}$, bark $380-670 \mathrm{~kg} \cdot \mathrm{m}^{-3}$ and small-wood 490-650 kg.m ${ }^{-3}$. Small-wood has the lowest variation coefficients (4-9\%). Wood has only slightly higher (4-10\%) and the bark has the highest one (7-17\%). The Black locust has the highest wood basic density, almost $650 \mathrm{~kg} \cdot \mathrm{m}^{-3}$, but regarding the bark and small-wood fractions it is the Turkey oak with density of approximately $670 \mathrm{~kg} \cdot \mathrm{m}^{-3}$ and $655 \mathrm{~kg} \cdot \mathrm{m}^{-3}$. According to Student's t-test, most of the statistically significant differences are between biomass fractions. There are insignificant differences between wood and bark in alder, hornbeam and Sessile oak. They continue between wood and small-wood in Sessile oak, birch and beech and between bark and small-wood in Sessile oak.

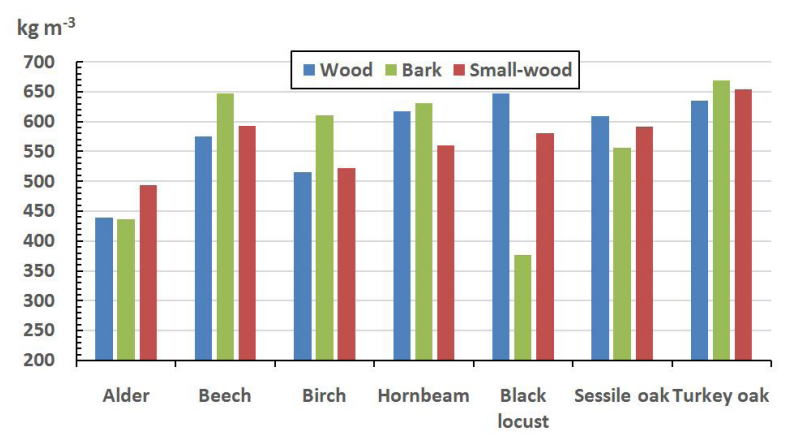

Fig. 3: The basic density of the biomass fractions (Wood, Bark, Small-wood) of species. 


\section{Differences in wood, bark and small-wood basic densities between tree species}

The range in wood basic density between the investigated tree species $\left(440-650 \mathrm{~kg} \cdot \mathrm{m}^{-3}\right)$ is relatively large (Fig. 4). There are statistically significant differences between most species. Differences are insignificant only between tree species with higher density. Specifically, between the Black locust-Turkey oak, hornbeam, between Turkey oak- Sessile oak, hornbeam and between Sessile oak-hornbeam. Alder, birch and beech have wood basic density statistically significantly lower compared to the other four tree species.

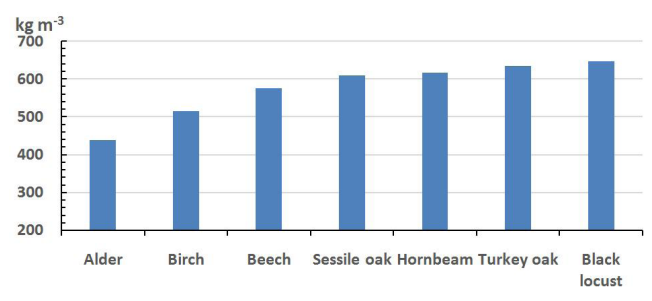

Fig. 4: The wood basic density of the species.

The bark basic density between tree species examined has a wider span of $380-670 \mathrm{~kg} \cdot \mathrm{m}^{-3}$ (Fig. 5). There are statistically significant differences between most species. No significant differences were found between five tree species with higher bark basic density. Specifically, between the beech-Turkey oak, the hornbeam and birch, between the birch-Sessile oak and the hornbeam and between the Turkey oak-hornbeam. The Black locust and alder species have bark basic density statistically significantly lower compared to the other five tree species.

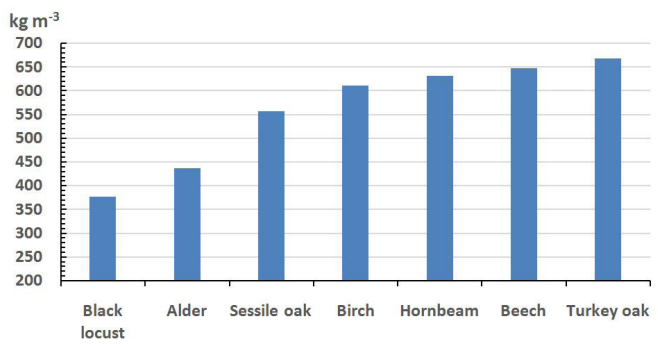

Fig. 5: The bark basic density of the species.

The small-wood basic density (Fig. 6) is in the narrowest range, specifically from 490 to $590 \mathrm{~kg} \cdot \mathrm{m}^{-3}$. Only the Turkey oak with its density of approximately $650 \mathrm{~kg} \cdot \mathrm{m}^{-3}$ excels in this range. This narrow range also resulted in a larger number of statistically insignificant differences between tree species. The density of Sessile oak, beech, hornbeam and birch differs insignificantly from the density of Black locust. The density of Sessile oak and hornbeam insignificantly differs from the density of beech. The group of insignificant differences also includes pairs of birchhornbeam, birch-alder and Sessile oak-hornbeam. 


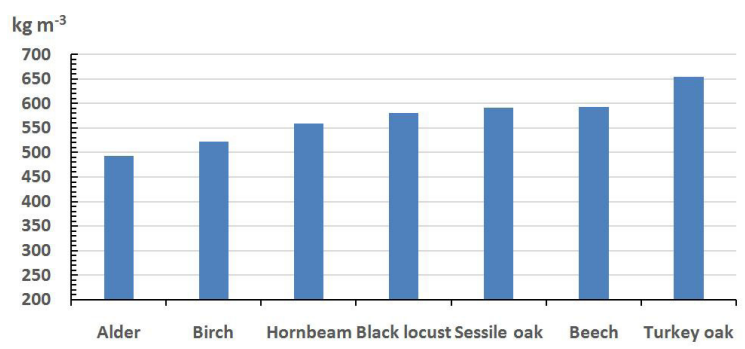

Fig. 6: The small-wood basic density of the species.

Our results correspond quite well with the knowledge published so far. Results are most widespread for the wood, which has the highest share in tree biomass. According to the derived basic density of wood, we can divide the tree species studied into three groups. First, Sessile oak, hornbeam, Turkey oak and Black locust with basic density of $610-650 \mathrm{~kg} \cdot \mathrm{m}^{-3}$, then birch and beech with density of $515-575 \mathrm{~kg} \cdot \mathrm{m}^{-3}$ and in the end the alder with density of $440 \mathrm{~kg} \cdot \mathrm{m}^{-3}$. This range also corresponds well with the results of other authors. Požgaj et al. (1997) gives $560 \mathrm{~kg} \cdot \mathrm{m}^{-3}$ for beech and 600-650 kg:m ${ }^{-3}$ for Black locust and hornbeam. Knigge and Schulz (1966) in Pretzsch (2009) give 520-560 kg. $\mathrm{m}^{-3}$ for hardwoods and $650 \mathrm{~kg} \cdot \mathrm{m}^{-3}$ for Black locust. On the lower range $\left(600 \mathrm{~kg}^{-3}\right)$, the Black locust density is found, derived by Klašnja and Kopitovič (1992). The closest values were achieved by Koman and Feher (2015). Thus, approximately $570 \mathrm{~kg} \cdot \mathrm{m}^{-3}$ for beech wood, $590 \mathrm{~kg} \cdot \mathrm{m}^{-3}$ for Sessile oak and $630 \mathrm{~kg} \cdot \mathrm{m}^{-3}$ for Turkey oak. The reason for the close results is probably the same methodology of collecting and processing the experimental material, but also the close natural conditions of their origin. Similar comparisons for bark and small-wood basic density of investigated hardwoods are not possible because the authors failed to obtain reliable resources. Generally, however, it can be stated that the derived basic densities for all three fractions correspond not only to their macro- and microscopic structure, but also to the chemical composition. For wood, they correspond especially to the width of annual rings, the presence of the core wood including false one, the structure and thickness of the conductive tissues, the thickness of their walls (Chovanec 1985), a proportion of cellulose, hemicellulose, lignin and the like. For bark, it may be different structure, a proportion of cambium, phloem, pheloderm and suberoderm, inorganic substances and mechanical (sclerenchymatic) tissues (Požgaj et al. 1997). In these tissues, the proportion and shape of mechanical cells (sclereids) is crucial. Of broadleaved species, beech has the highest proportion of them (40-60\%) and then hornbeam (20-30\%). The highest bark basic density of almost $670 \mathrm{~kg} \cdot \mathrm{m}^{-3}$ reaches Turkey oak, which has thick layers of thick-walled cork. Black locust, alder and Sessile oak have lower bark basic density because they contain phloem, which is close to wood in its chemical composition.

\section{CONCLUSIONS}

For an objective evaluation of forest stands production, it is necessary to know not only the volume but also the weight of biomass produced. For its determination, the conversion from volume units to weight requires to know the basic density by tree species and biomass basic fractions. Basic density was derived from tree biomass samples taken in Slovakia. For 7 tree species (alder, beech, birch, hornbeam, Black locust, Sessile oak and Turkey oak), 73 sample trees were felled in total. Four wood samples containing the bark were cut from each tree. The first 
sample was taken from the foot of the trunk, the second from the middle and the third from the crown part of the trunk. All three samples were divided into wood and bark. The fourth sample represents the small-wood which is the wood of the branches with bark.

The volume of green samples was measured in graduated cylinders with a precision of $1 \mathrm{ml}$. All samples were then dried at $103 \pm 2^{\circ} \mathrm{C}$ and after that their weight was determined to within $0.01 \mathrm{~g}$. The basic density was calculated for each sample according to Eq. 1 . Its variability was studied. The statistically significant effect has been shown in tree species, fractions of biomass and locations on the tree. The average basic density of the species varies from 440 to $650 \mathrm{~kg} \cdot \mathrm{m}^{-3}$ for wood, for bark it is $380-670 \mathrm{~kg} \cdot \mathrm{m}^{-3}$ and for small-wood it reaches up to $490-650 \mathrm{~kg} \cdot \mathrm{m}^{-3}$. The variation coefficients of basic density are in the range of $5-10 \%$ for wood, $7-17 \%$ for bark and $4-9 \%$ for small-wood. Alder and Black locust tree species have the lowest and highest density of wood, Black locust and Turkey oak of bark and alder and Turkey oak of small-wood. Three groups of tree species were formed according to the determined wood basic density. Sessile oak, hornbeam, Turkey oak and Black locust with values of $610-650 \mathrm{~kg} \cdot \mathrm{m}^{-3}$, birch and beech with $515-575 \mathrm{~kg} \cdot \mathrm{m}^{-3}$ and alder with density of $440 \mathrm{~kg} \cdot \mathrm{m}^{-3}$.

The derived values of wood, bark and small-wood density will be used in the conversion of forest biomass production in existing volume units $\left(\mathrm{m}^{3}\right)$ to the weight of biomass in dry matter $(\mathrm{kg})$ and ultimately for the production of calorific value $(\mathrm{J})$. This result is expected in 2021.

\section{ACKNOWLEDGEMENT}

This work was supported by the Slovak Research and Development Agency under the contract No. APVV-16-0344.

\section{REFERENCES}

1. Banski, A., Dzurenda, L., 2014: Hustota a sypná hmotnosṫ energetickej štiepky z dendromasy plantážnicky pestovaných porastov rýchlorastúcich drevín. (Density and bulk density of green wood chips from dendromass of short rotation coppice grown on plantations). Acta Facultatis Xylologiae Zvolen 56(2): 17-26.

2. Husch, B., Beers, T.W., Kershaw, J.A., 2003: Forest mensuration. John Wiley \& Sons. New Jersey, 443 pp.

3. Chovanec, D., 1985: Morfológia bunečných elementov listnatých drevín. (Morphology of cell elements of decidious tree species). Vedecko-pedagogické aktuality. VŠLD, Zvolen, $122 \mathrm{pp}$.

4. Jelonek, T., Pazdrowski, W., Tomczak A., 2009: The effect of biological class and age on physical and mechanical properties of European larch (Larix decidua MILL.) in Poland. Wood Research 54(1): 1-14.

5. Klašnja, B., Kopitovič, Š., 1992: Some properties of Robinia wood obtained from trees grown in provenance field experiments. Drevársky výskum 134: 1-8.

6. Koman, S., Feher, S., 2015: Basic density of hardwoods depending on age and site. Wood Research 60(6): 907-912.

7. Kupka, K., 2013: QC. Expert 3.1. (User's manual). TryloByte, Ltd. Pardubice, 266 pp.

8. Lieskovský, M., 2015: Vybrané produkčné a energetické vlastnosti topol’a Populus x Euroamericana klon Max 4 (Selected production and energetic properties of Populus $x$ Euroamericana clone Max 4). Acta Facultatis Xylologiae Zvolen 57: 127-133. 
9. Matovič, A., Šlezingerová, J., 1992: Konvenční hustota dřeva větví smrku obecného (Picea abies Karst.), (Basic density of branchwood in Norway Spruce (Picea abies /L./ Karst.). In: Symp: Les, drevo, ekológia, Sekcia 4. Štruktúra a vlastnosti dreva v technologickom využití. Pp 53-59, Technická univerzita, Zvolen, Pp 53-59.

10. Munoz, G.R., Anta, M.B., 2010: Physical properties of thinning wood in maritime pine (Pinus pinaster Ait.): case study. European Journal of Forest Research 129(6): 1037-1045.

11. Niemz, P., Sonderegger, W., 2003: Untersuchungen zur Korrelation ausgewählter Holzeigenschaften untereinander und mit der Rohdichte unter Verwendung von 103 Holzarten. Schweizerische Zeitschrift für Forstwesen 154(12): 489-493.

12. Pastor, M., Dzurenda, L., Banski, A., Slobodník, B., Benčat', T., 2017: Energetic characteristics of the dendromass of branches in the sweet chestnut (Castanea sativa Mill.). Acta Facultatis Xylologiae Zvolen 59(1): 127-135.

13. Petráš, R., Mecko, J., Neuschlová, E., 2010: Density of basic components of above-ground biomass of poplar clones. Wood Research 55(4): 113-122.

14. Petráš, R., Mecko, J., Oszlányi, J., Petrášová, V., Jamnická, G., 2013: Landscape of Danube inland-delta and its potential of poplar bioenergy production. Biomass and Bioenergy 55: 68-72.

15. Petráš, R., Mecko, J., Krupová, D., Slamka, M., Pažitný, A., 2019: Aboveground biomass basic density of softwoods tree species. Wood Research 64(2): 205-2012.

16. Petty, J.A., Macmillan, D.C., Steward, C.M., 1990: Variation of density and Growth Ring Width in Stems of Sitka and Norway Spruce. Forestry 63(1): 39-49.

17. Požgaj, A., Chovanec, D., Kurjatko, S., Babiak, M., 1997: Štruktúra a vlastnosti dreva. (Structure and properties of wood). Príroda. Bratislava, $485 \mathrm{pp}$.

18. Pretzsch, H., 2009: Forest Dynamics, Growth and Yield. Springer. Berlin Heidelber $664 \mathrm{pp}$.

19. Repola, J., 2006: Models for vertical wood density of Scots pine, Norway spruce and birch stems, and their application to determine average wood density. Silva fennica 40(4): 673-685.

20. Schönfelder, O., Zeidler, A., Borůvka, V., Bílek, L., 2017: Influence of site conditions and silvicultural practice on the wood density of the Scots pine (Pinus sylvestris L.) - a case study from the locality of Doksy, Czech Republic. Journal of Forest Science 63(10): 457-462.

21. Šmelko, Š., Wenk, G., Antanaitis, V., 1992: Rast, štruktúra a produkcia lesa. (Forest growth, structure and production). Príroda, Bratislava, $342 \mathrm{pp}$.

22. Tomczak, A., Jelonek, T., 2013: Radial variation in the wood properties of Scots pine (Pinus sylvestris L.) grown on former agricultural soil. Forest Research Papers 74: 171-177.

23. Vavrčík, H., Gryc, V., 2012: Analysys of the annual ring structure and wood density relations in english oak and Sessile oak. Wood Reseach 57(4): 573-580.

24. Wimmer, R., 1991: Beziehungen zwischen Jahrringparametern und Rohdichte von Kiefernholz. Holzforschung und Holzverwertung 43(4): 79-82.

25. Zeidler, A., Borůvka, V., 2016: Wood Density of Northern Red oak and Pedunculate oak Grown in Former Brown Coal Mine in the Czech Republic. BioResources 11(4): 9373-9385. 
Rudolf Petráš́, Julian Mecko, Danica Krupová

National Forest Centre - Forest Research Institute in Zvolen

T. G. MASARYKa 22

96092 ZvOLEN

Slovak Republic

*Corresponding author: petras@nlcsk.org

Andrej Pažitný

Pulp and Paper Research Institute

Dúbravská Cesta i4

84I O4 BratisLava

Slovak Republic 
